\title{
The Effect Of Brand Image And Promotion On The Purchase Decision Of Tony Jack Jeans Product At DNA Store South Of Tangerang
}

\author{
Suharni Rahayu \\ Economy and Business Faculty, Universitas Pamulang, Indonesia. \\ ${ }^{*}$ Corresponding author: \\ Email:Dosen00964@unpam.ac.id
}

\begin{abstract}
.
This study aims to determine the effect of Brand Image on Purchase Decisions on Tony Jack's Jeans products, to determine the effect of Promotion on Tony Jack's jeans product purchase decisions and to determine the effect of Brand Image and Promotion on Tony Jack's Jeans product purchasing decisions at DNA Stores in general. simultaneous. By using the formula method of T Test and F Test. Brand Image has a positive and significant influence on Purchase Decisions where the value of tcount $>$ ttable $(5.224>1.986)$ and sig $<0.05(0.000<0.05)$ Brand Image Variable (X1) partially positive effect on Purchase Decision. Promotion has a positive and significant effect on purchasing decisions where the value of tcount $>$ ttable $(8.728>1.986)$ and sig $<0.05(0.000<0.05)$. Promotion variable (X2) partially positive effect on Purchase Decision. Brand Image and Promotion have a positive and significant influence on Purchase Decisions simultaneously where the fcount $>$ ftable is $122.214>2.70$ and the sig value $<0.05$ or $0.000<0.05$ means that there is a positive and significant influence between Brand Image and Promotion of Purchase Decisions. The multiple linear regression equation $Y=4.817+0.308 X 1+$ $0.587 X 2+e$, means that the constant value is 4.817 , the coefficient value of $X 1$ is 0.308 and the coefficient of X2 is 0.587. Based on the calculation results, it is known that the coefficient of determination (R2) obtained is 0.563. This means that 56.3\% of Purchase Decisions can be explained by Brand Image (X1) and Promotion (X2) variables, while 43.7\% of Purchase Decisions are influenced by other variables not examined, such as Price, Service Quality and others.
\end{abstract}

Keywords: Brand Image, Promotion, Purchase Decision

\section{INTRODUCTION}

In this era of globalization, marketing is very important for this nation which is marked by the increasing increase in science and technology, because basically this management deals with common goals, ways people work and the use of existing resources.The level of competition in the business world in Indonesia is very tight because every company is always trying to increase market share and reach new consumers. Companies must be able to survive and win the competition, so that the company's goals are achieved. Basically, the more competitors, the more choices consumers have to be able to choose products that match their expectations. 
Intense competition makes it increasingly difficult for companies to increase the number of consumers.

The number of players in the market with all kinds of product advantages offered makes it increasingly difficult for companies to seize competitors' markets. Intense competition will indirectly affect a company in maintaining market share, the company must work hard in maintaining its brand image. Because it is an effort to maintain a brand image is an important thing that must be done by the company. A company in issuing products should be adjusted to the needs and desires of consumers. That way, the product can compete in the market, thus making consumers have many alternative product choices before making a decision to buy a product offered. [1]

\begin{tabular}{|c|c|c|}
\hline MEREK & TBI & TOP \\
\hline LEVT'S & $31,1 \%$ & TOP \\
\hline LEA & $13,5 \%$ & TOP \\
\hline NEVADA & $7,4 \%$ & - \\
\hline LOGO & $6,7 \%$ & - \\
\hline LOIS & $6,1 \%$ & - \\
\hline
\end{tabular}

Fig 1. Top Brands of Jeans in 2019

From the table above, it is clear that the Tony Jack brand was not included in the top brand of jeans. Brand is the biggest asset source for the company. A company operates to earn a profit or profit, as well as to maintain the viability of its business. A company to win the competition, is required to carry out a marketing strategy for the products produced. In conditions of increasing competition for similar products and consumer behavior that tends to want to try new brands issued by competing companies to get satisfaction, more benefits, and fulfill curiosity about the new brand.Along with economic and technological developments as well as business competition in the global market, companies compete to be able to provide products and services that are more satisfying to customers and offer competitive prices, this is done in order to get new customers and retain their customers.

The strategy used by DNA Stores is to promote its products with various strategies.Promotion is a form of marketing communication which is a marketing activity that seeks to disseminate information, influence/persuade and remind the target market of the products offered by the company concerned.[2] DNA shop is a business engaged in Convection. was founded on April 24, 2010 in Bintaro. Regarding this, the DNA store sells Tony Jack's branded jeans. Purchasing decisions is consumer behavior is the buying behavior of final consumers, both individuals and households, who buy products for personal consumption. There are several stages that consumers do in the decision process to buy or not. 
After buying a product, consumers will feel satisfied or dissatisfied with the product they bought, if consumers are not satisfied they will switch to another brand. The consumer buying process begins when the purchaser recognizes a need or problem. The need arises from internal and external stimuli of consumers. [3] Based on the monitoring carried out on several things that influence consumer purchasing decisions in buying jeans with the Tony Jack brand, including consumers see whether the product and brand is of quality or not. So the researcher is interested in taking the title "The Effect Of Brand Image and Promotion On The Purchase Decision Of Tony Jack Jeans Product At DNA Store South Of Tangerang “.

\section{LITERATURE REVIEW \\ Brand Image}

Brand image is defined as consumer perceptions and preferences for brands, as reflected by various kinds of brand associations that exist in consumers' memories".[4] Although brand associations can occur in various forms, they can be divided into performance associations and image associations related to brand attributes and advantages. Brand image is a representation of the overall perception of the brand and formed information and past experiences of the brand. The image of the brand is related to attitudes in the form of beliefs and preferences for a brand. Brand image is a concept created by consumers for subjective reasons and personal emotions. [5] Brand Image Indicators:Brand Identity, Brand Personality, Brand Association, Brand Attitude and Behavior and Brand Benefits and Advantages . [6]

\section{Promotion}

Promotion is an activity carried out by a company to communicate the benefits of a product and as a tool to influence consumers in purchasing activities or using services according to their needs. [7] This is different from the notion of promotion which defines promotion as an exercise in information, persuasion and vice versa by persuading people to become informers. [8] Promotion Indicator: Advertising, Sales Promotion, Individual Sales, Public Relations and Direct Selling. [9]

\section{Purchase Decision}

Purchasing decisions are a process where consumers recognize the problem, seek information about a particular product or brand and evaluate how well each alternative can solve the problem, which then leads to a purchase decision. [10] Purchase decision Indicators:Problem Recognition,Information Search,Evaluation of Alternatives,Purchase Decision and Post Purchase Behavior . [11]

\section{METHODS}

Data collection methods in this study using a survey method conducted at the DNA shop. Where the techniques used in data collection are: Observation,Interview and Questionnaire.The authors conducted research at the DNA shop which is located at Jl. Bintaro Utama 1 No. 16 South Tangerang. research methods based on the 
philosophy of positivism, are used to examine certain populations or samples, sampling techniques are generally carried out randomly, data collection uses research instruments, data analysis is quantitative/statistical with the aim of testing predetermined hypotheses. [12] In this study, the population used were consumers at the DNA shop, amounting to 3875 people.

From this research, the sampling technique that the researcher uses is Simple Random Sampling.Simple random sampling is sampling from a population that is carried out randomly without regard to the strata in the population. To determine the number of samples, the researchers used the slovin formula. [13] The sample that will be used in this research is 97 people. The measurement scale used in this study is the Likert scale. Method of Analysis Using Data Quality Test consisting of Validity Test, Reality Test, then using Classical Assumption Test consisting of Data Normality Test, Multicollinearity Test, Heteroscedasticity Test, Autocorrelation Test, to further use the Hypothesis Test, namely $\mathrm{t}$ test and $\mathrm{F}$ test and continue with Multiple Regression Analysis Test and the last is the Coefficient of Determination test. [14]

\section{RESULT AND DISCUSSION}

The result of this research is to obtain an overview of the Quantitative Method. To support the research, the authors distributed questionnaires to 97 respondents, namely as many as samples considered to have met the ideal sample requirements based on the Slovin formula with an error rate of $10 \%$. Judging from the characteristics of respondents from data processing, 97 respondents were used as samples. The analysis of the results of this study is a quantitative descriptive explanation using SPSS version 22 software to analyze research data

Table 1. Validity Test

\begin{tabular}{|c|c|c|c|c|}
\hline \multicolumn{2}{|r|}{ Variables } & \multirow[b]{2}{*}{ tem } & & \multirow[t]{2}{*}{$\mathbf{V}$} \\
\hline & & & alidity & \\
\hline & Brand & & & $\mathrm{V}$ \\
\hline \multirow[t]{3}{*}{ Image } & & 0 & alid & \\
\hline & Promotion & & & V \\
\hline & & 0 & alid & \\
\hline & Purchase Decision & & & $\mathrm{V}$ \\
\hline
\end{tabular}

Based on the data in the table 1 above, all variables obtained by the value of $r$ count $>r$ table $(0.200)$, thus all questionnaire items are declared valid. For this reason, the questionnaire used is feasible to be processed as research data.

Table 2. Reliability Test

\begin{tabular}{cccc}
\hline Variables & $\begin{array}{c}\text { Alpha } \\
\text { Cronbach }\end{array}$ & ty & Validi \\
\hline C & 0,881 & & Reliab \\
Brand Image & & le & \\
\hline
\end{tabular}




\begin{tabular}{rccc}
\hline Promotion & 0,858 & & Reliab \\
& & le & \\
\hline Purchase & 0,886 & Reliab \\
Decision & & le & \\
\hline
\end{tabular}

Based on the test results in the table 2 above, it shows that the Brand Image variable (X1), Promotion (X2) and Purchase Decision (Y) are declared reliable, this is evidenced by each variable having a Chronbath Alpha value greater than 0.600. [15]

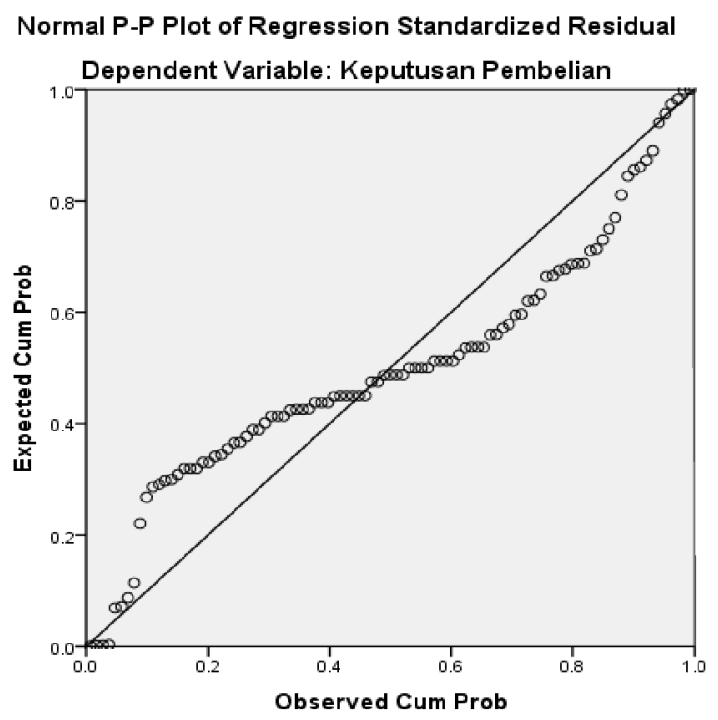

Fig 2. Normality Test P-P Plot Of Regression Standardized Residual

It can be seen from Figure 2 above that the points spread around the line and follow the diagonal, it can be interpreted that the residual value resulting from the regression is normal.

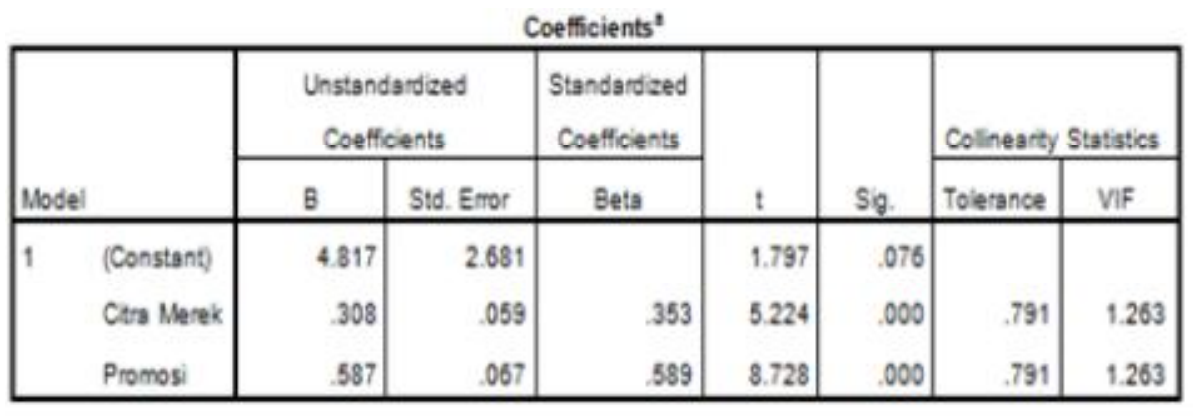

Fig 3. Multicollinearity Test Results

Looking at the calculation results from the Multicollinearity test in Figure 3, the tolerance value does not have an independent variable that has a tolerance value of less than 0.10 with a tolerance value of the work stress variable of 1,000. Meanwhile, the results of the calculation of the Variance Inflation Factor (VIF) value also show the same thing, namely the absence of the VIF value of the independent variable which has a VIF value of more than 10 with a VIF value of the work stress variable of 
1,000. Referring to the calculation results of tolerance and VIF values, it can be concluded that there is no multicollinearity of the work stress variable in the regression model.

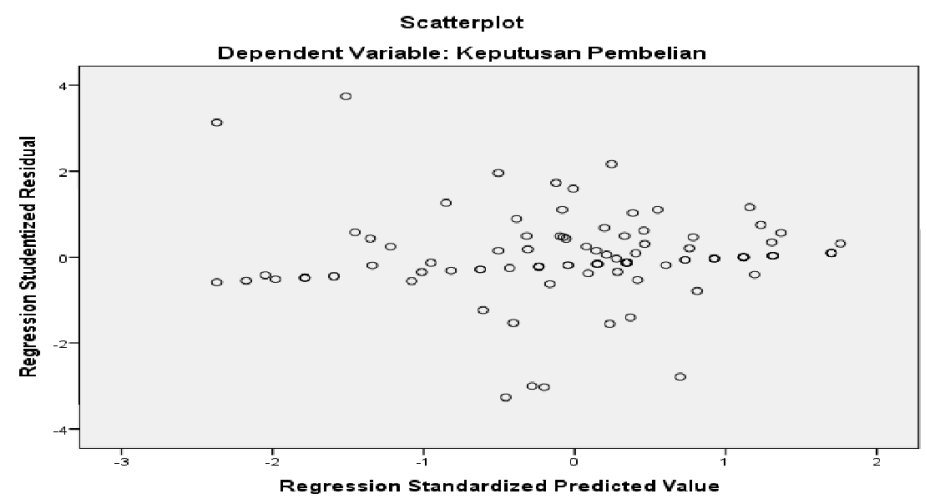

Fig 4. Heteroscedasticity Test Results

Based on the heteroscedasticity test in Figure 4 above shows that the points are randomly distributed, do not form a clear specific pattern, and are spread both above and below the number 0 (zero) on the $\mathrm{Y}$ axis, this means that there is no deviation from the classical assumption of heteroscedasticity in the regression model made.

Model Summary?

\begin{tabular}{|l|r|r|r|r|r|}
\hline Model & R & R Square & $\begin{array}{c}\text { Adjusted R } \\
\text { Square }\end{array}$ & $\begin{array}{r}\text { Std. Error of } \\
\text { the Estimste }\end{array}$ & Durbin-Watson \\
\hline 1 & $.753^{\circ}$ & .567 & .459 & 2.47081 & .599 \\
\hline
\end{tabular}

a. Predictors: (Constant), Brand Image, Promotion

b. Dependent Variable: Purchase Decision

Fig 5. Durbin-Watson Autocorrelation Test Result

In Figure 5 above, it can be seen that the Durbin-Watson value is 0.599 . These results indicate that the DW value between the second interval is between -2 to +2 . So it can be concluded that the regression model does not occur autocorrelation.

\begin{tabular}{|c|c|c|c|c|c|c|}
\hline \multicolumn{7}{|c|}{ Coefficients ${ }^{2}$} \\
\hline & & \multicolumn{2}{|c|}{ Unstandardized Coefficients } & $\begin{array}{l}\text { Standardized } \\
\text { Coefficients }\end{array}$ & \multirow[b]{2}{*}{$\mathrm{T}$} & \multirow[b]{2}{*}{ Sig. } \\
\hline \multicolumn{2}{|c|}{ Model } & 且 & Std. Error & Beta & & \\
\hline \multirow[t]{3}{*}{1} & (Constant) & 4.817 & 2.681 & & 1.797 & .076 \\
\hline & Citra Merek & .308 & .059 & .353 & 5.224 & .000 \\
\hline & Promosi & 587 & .067 & 589 & 8.728 & .000 \\
\hline
\end{tabular}

a. Dependent Variable: Purchase Decision

Fig 6. Multiple Linear Regression Test Results and t Test Results (Partial Test)

From Figure 6, the results of the calculation of the independent variables can be arranged in the following model: $\mathrm{Y}=4.817+0.308 \mathrm{X} 1+0.587 \mathrm{X} 2$ The constant 
value of the equation above is 4.817. Based on the figure 6 , it is known that Brand Image has a positive effect with the indicated value of tcount greater than ttable (5.224 $>1.986$ ), then Brand Image also has a significant effect on Purchase Decisions with a regression value of 0.308 . Which means that the analysis above proves that the quality of service is proven to have an effect on purchasing decisions. Promotion has a positive effect with the indicated value of tcount is smaller than ttable $(8.728>1.986)$, then Promotion also has a significant effect on Purchase Decisions with a regression value of 0.587 . Which means that the analysis above proves that the Promotion is proven to have an effect on the Purchase Decision.

ANOVA*

\begin{tabular}{|ll|r|r|r|r|r|}
\hline \multicolumn{1}{|l|}{} & Model & Sum of Squares & \multicolumn{1}{c|}{ Df } & Mean Square & \multicolumn{1}{c|}{$F$} & \multicolumn{1}{c|}{ Sig. } \\
\hline 1 & Regression & 1745.333 & 1 & 1745.333 & 122.214 & $.000^{\circ}$ \\
& Residual & 1356.688 & 95 & 14.281 & & \\
Total & 3102.021 & 96 & & & \\
\hline
\end{tabular}

Fig 7. F Test Results (Simultaneous)

From Figure 7 above, the value of Fcount $=122,214$ is obtained. This value is then consulted with Ftable, with $\mathrm{dk}$ in the numerator $=\mathrm{k}=2$ and $\mathrm{dk}$ in the denominator $=(n-k-1)=(97-2-1)=94$ and an error rate of 5\%. Then Ftable $=2.70$. From the results of the $\mathrm{F}$ (simultaneous) test, it was obtained that Fcount was greater than Ftable $(122.214>2.70)$, this means that the point of significance test results and Fcount on the normal distribution curve is in the acceptance region of Ha, meaning that the independent variables are Brand Image and Promotions simultaneously have a significant influence on Purchase Decisions at DNA Stores.

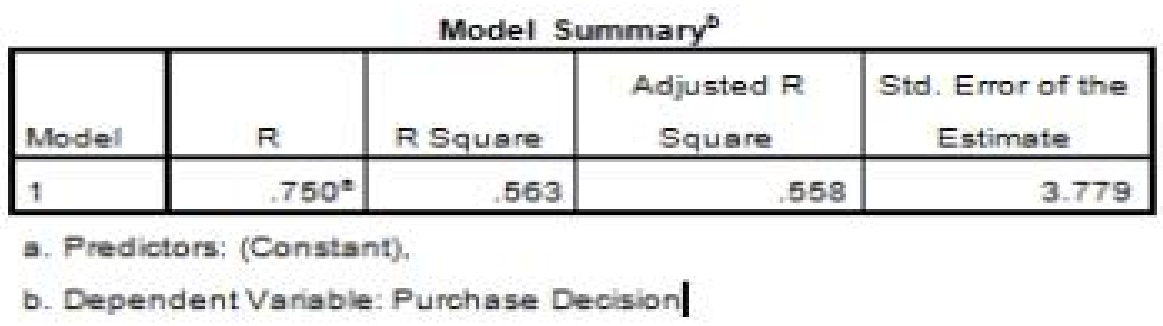

Fig 8. Coefficient of Determination Test Results (R2)

Based on figure 8 The magnitude of the coefficient of determination (R2) is 0.563 or equal to $56.3 \%$. This figure means that service quality and price have a positive and significant effect on purchasing decisions by $56.3 \%$. While the rest $(100 \%-56.3 \%=43.7 \%)$ is influenced by other variables outside that are not examined. From these data, it is explained that there are other variables outside of the Brand Image and Promotion variables that can affect Purchase Decisions at DNA Stores. 


\section{CONCLUSION}

From the results of data analysis and discussion in the previous chapter, it can be concluded as follows: Brand Image has a significant effect on purchasing decisions. It is supported Product quality regression coefficient (X1) is 0.308 , The t test which states $t$ count $(5,224>1,986)$ means that the effect of product quality on purchasing decisions is significant. Promotion has a significant effect on purchasing decisions. It is supported by Promotion regression coefficient (X2) is 0.587 . The t test which states $t$ count $(8.728>1.986)$ means that the effect of promotion on purchasing decisions is significant.

Brand Image and Promotion have a significant effect on purchasing decisions. It is supported .The coefficient of determination R2 of 0.563 means that the variation of the purchasing decision variables can be explained by variations in product quality, promotion and design variables of $56.3 \%$ while the remaining $43.7 \%$ is explained by other variables outside the regression model. The f test which states that $f$ count $(122.214>2.70)$ means that the influence of brand image and promotion on purchasing decisions is significant.

\section{REFERENCES}

[1] Tanihattu, M. M. (2015). EKUITAS MEREK DAN PENGARUHNYA TERHADAP KEPUASAN PENGGUNA SMARTPHONE DI KOTA AMBON. ARTHAVIDYA, 17(1).

[2] Buchari Alma., 2014. Manajemen Pemasaran dan Pemasaran Jasa. CV. Alfabeta, Bandung.

[3] Kotler, Philip dan Amstrong, Gary, (2014), Principles of Marketin, 12th Edition, Jilid 1 Terjemahan Bob Sabran Jakarta : Erlangga.

[4] Ristanti, N. (2017). Pengaruh Iklan, Promosi Penjualan dan Citra Merek Honda Terhadap Keputusan Pembelian Sepeda Motor Vario (Studi Pada Kecamatan Balen Bojonegoro) (Doctoral dissertation, Universitas Muhammadiyah Gresik).

[5] Dewi, Ferinda. 2009:203. "Pengaruh Citra Merek Terhadap Keputusan Pembelian Konsumen Pengguna Sepatu Converse”. Jurnal Pemasaran Studi Manajemen Vol. 3 Kendari

[6] Kotler, Philip., Keller, Kevin L. (2013). Manajemen Pemasaran, Jilid Kedua, Jakarta: Erlangga.

[7] Lupiyoadi, Rambat. 2013. Manajemen Pemasaran Jasa Berbasis Kompetensi (Edisi 3). Jakarta: Salemba Empat.

[8] Alma, Buchari. (2013). Manajemen Pemasarandan Pemasaran Jasa. Alfabeta : Bandung.

[9] Kotler, Philip dan Armstrong, Gary. 2012. Principles of Marketing. New Jersey: Prentice Hall

[10] Fandi, Tjiptono. 2014. Service, Quality \& Satisfaction. Edisi 3. Yogyakarta: Penerbit Andi.

[11] Kotler, Philip, and Kevin Lane Keller. 2016. Manajemen Pemasaran. Edisi 13 J. Jakarta: 
Erlangga.

[12] Sugiyono. (2016). Metode Penelitian Kuantitatif, Kualitatif dan R\&D. Bandung: Alfabeta

[13] Darmadi, Hamid. 2014. Metode Penelitian Pendidikan Sosial. Bandung: Alfabeta.

[14] Kencana, P. N. (2020). The Effect of Brand Image on PT Shaza Food Product Purchase Decision (Case Study in South Tangerang Area). Journal of Business, Management, \& Accounting, 2(2), 219-226.

[15] Kencana, P. N., \& Nurwita, N. (2021). PENGARUH KUALITAS PRODUK DAN BRAND IMAGE TERHADAP KEPUTUSAN PEMBELIAN PRODUK PT SHAZA FOOD (STUDI KASUS DI AREATANGERANG SELATAN). MEDIA BINA ILMIAH, 15(10), 5531-5536. 